\title{
ซี่ Contributors
}

Colleen Callaban is Assistant Professor of Economics, Lehigh University. She completed her Ph.D. at the University of North Carolina in 1987, with a dissertation called "Movements in Aggregate Price Uncertainty in the United States, I884-198I." She has written articles on the selfsufficiency of the South, the financial history of the United States, and international trade.

Lance E. Davis is Mary Stillman Harkness Professor of Social Science, Division of the Humanities and Social Sciences at California Institute of Technology, and a research associate of the National Bureau of Economic Research. He is one of the founding fathers of the "new economic history" and a past president of the Economic History Association. His publications include Institutional Change and American Economic Growth (Cambridge, 197I), written with Douglass North; Mammon and the Pursuit of Empire (Cambridge, 1986), written with Robert Huttenback; and numerous articles on American economic history.

Stanley Engerman is Professor of Economics and History, Department of Economics, University of Rochester, a research associate of the National Bureau of Economic Research, and a past president of the Economic History Association. He has written about slavery in the United States and the West Indies as well as about U.S. economic growth. With Robert Fogel he is coauthor of Time on the Cross (Boston, 1974); coeditor of The Reinterpretation of American Economic History (New York, 197I); and coeditor (with Robert Gallman) of Long-Term Factors in American Economic Growth (Chicago, I986).

Robert Fogel is the Charles R. Walgreen Professor of American Institutions and Director of the Center for Population Economics, University of Chicago, and a research associate of the National Bureau of Economic Research. He has served as president of both the Economic History Association and the Social Science History Association, and as director of the National Bureau of Economic Research's Program on the Development of the American Economy. He has written extensively on the issues 
of slavery and American economic growth. His publications include Time on the Cross and The Reinterpretation of American Economic History (written with Engerman); Railroads and American Economic Growth (Baltimore, 1964); and Without Consent or Contract (New York, 1989).

Louis Galambos is Professor of History, The Johns Hopkins University, past president of the Economic History Association, former editor of the Journal of Economic History, and editor of The Papers of Dwight David Eisenhower. He has written extensively in the area of U.S. business history, including The Public Image of Big Business in America, 1880-1940 (Baltimore, 1975); The Fall of the Bell System: A Study in Prices and Politics, with Peter Temin (New York, 1987); and The Rise of the Corporate Commonwealth: United States Business and Public Policy in the Twentieth Century, with Joseph Pratt (New York, 1988).

J. Matthew Gallman is Associate Professor of History, Loyola College, Baltimore. He is the author of Mastering Wartime: A Social History of Philadelphia During the Civil War (Cambridge and New York, 1990).

Robert Gallman is Kenan Professor of Economics and History, chair, Department of Economics, University of North Carolina at Chapel Hill, and a research associate of the National Bureau of Economic Research. He has served as president of both the Southern Economic Association and the Economic History Association, and as editor of the Journal of Economic History. His extensive research has provided the empirical basis for much of our knowledge of the nineteenth-century economy of the United States.

Claudia Goldin is Professor of Economics, Harvard University, and director of the National Bureau of Economic Research's Program on the Development of the American Economy. She is a former editor of the Journal of Economic History and has written numerous articles on labor history. Her publications include Urban Slavery in the American South, I820 to I860 (Chicago, 1976); Understanding the Gender Gap: An Economic History of American Women (Oxford, 1990); and Strategic Factors in NineteenthCentury American Economic History (edited with Hugh Rockoff) (Chicago, 1992).

Teresa Hutchins is Assistant Professor of Economics, Department of Economics, Ramapo College of New Jersey. Her dissertation, "The American Whale Fishery, I815-1900," was written at the University of North Carolina under the direction of Robert Gallman. She has collaborated with Gallman and Davis on numerous articles about the economics of the U.S. whaling industry, including "The Structure of the Capital Stock in Economic Growth and Decline: The New Bedford Whaling Fleet in the 
Nineteenth Century," in P. Kilby, ed., Quantity and Quiddity: Essays in U.S. Economic History (Middletown, Conn., 1987).

Charles P. Jones is Edwin Gill Professor of Finance, North Carolina State University. He is the author of Investments: Analysis and Management (New York, I985; 3d ed., 199I), Introduction of Financial Management (Homewood, Ill., I992), and many articles on financial economics.

Douglass North is Professor of Economics and director of the Center in Political Economy at Washington University in St. Louis. He is a former editor of the Journal of Economic History. His publications include The Economic Growth of the United States, I790-I860 (Englewood Cliffs, N.J., 196I); and Institutions, Institutional Change and Economic Performance (Cambridge, 1990).

William Parker is Phillip Golden Bartlett Professor of Economics and Economic History, Emeritus, Yale University. He has served as president of both the Agricultural History Society and the Economic History Association, and as editor of the Journal of Economic History. His work has encompassed not only empirical investigations of the United States but the broader issues of U.S. and European history, exemplified by his twovolume work Europe, America, and the Wider World (Cambridge, 1984 and 1991). He is editor of Trends in the American Economy in the Nineteenth Century (Princeton, 1964), and Economic History and the Modern Economist (Oxford, I986).

Barry Poulson is Professor of Economics, University of Colorado at Boulder. An expert in both economic history and economic development, he has published Value Added in Manufacturing, Mining, and Agriculture in the American Economy from I809 to I839 (New York, 1975); Economic History of the United States (New York, 198I); and a number of books and articles on economic development in Latin America and the Middle East.

Donald Schaefer is Professor of Economics, Washington State University. He has written on a variety of topics in the economic history of the United States, including slavery, migration, and railroads. His publications include $A$ Quantitative Description and Analysis of the Growth of the Pennsylvania Anthracite Coal Industry, 1820-1865 (New York, 1977).

Richard Sylla is Henry Kaufman Professor of the History of Financial Institutions and Markets and Professor of Economics, New York University, and research associate of the National Bureau of Economic Research. A former editor of the Journal of Economic History, he has written extensively on the topic of financial economic history. His publications include The American Capital Market, 1846-1914 (New York, 1975); The Evolution of 
the American Economy (New York, 1979; 2d ed., 1993), written with Sidney Ratner and James Soltow; and A History of Interest Rates, 3d ed. (New Brunswick, N.J., 1991), with Sidney Homer.

Thomas Weiss is Professor of Economics, University of Kansas, research associate of the National Bureau of Economic Research, and former editor of the Journal of Economic History. He is author of The Service Sector in the United States, I839 through I899 (New York, 1975); coauthor (with Fred Bateman) of $A$ Deplorable Scarcity (Chapel Hill, 198I); and author of many articles on the U.S. labor force in the nineteenth century.

Jack W. Wilson is Professor of Economics and Business at North Carolina State University. $\mathrm{He}$ has published a number of articles on financial history, including "Financial Market Panics and Volatility in the Long Run, 1830-1988" (with Sylla and Jones), in E. White, ed., Crashes and Panics: The Lessons from History (Homewood, Ill., 1990); and "A Comparison of Common Stock Returns, 1871-1925 with 1926-1985," Journal of Business (April 1987). 
American Economic Development in Historical Perspective 
